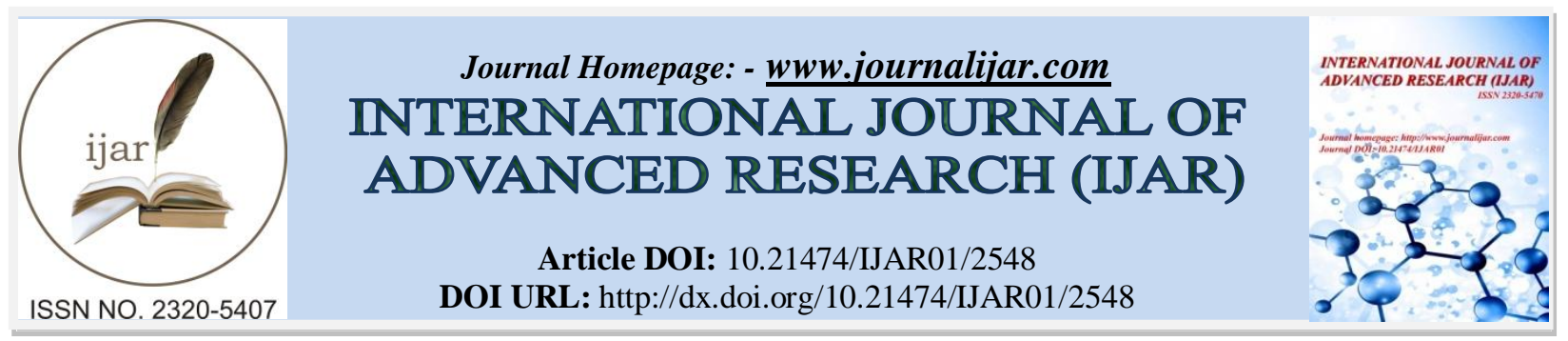

RESEARCH ARTICLE

\title{
SYNTHESIS OF 5-OXYCOUMARIN AND FUSED COUMARIN DERIVATIVES AND EVALUATION OF THEIR ANTITUMOR ACTIVITY.
}

\section{L.H.Alwahaibi.}

Chemistry Department, Science College,Princess Nourah bint Abdulrahman University, Riyadh, Saudi Arabia.

\section{Manuscript Info}

Manuscript History

Received: 27 October 2016

Final Accepted: 25 November 2016

Published: December 2016

Key words:-

5-oxycoumarin derivatives, anticancer,

liver HePG2.

\section{Abstract}

A series of 5-oxycoumarin derivatives 2-7 and 10-18 have been synthesized by reaction of 5-hydroxy-4,7-dimethyl coumarin 1 with different reagents.Benzopyrano[3,4-b]benzothiazine derivatives 8 and pyranocoumarin 9 were also prepared and screened for their in vitro antitumor activity against human liver cancer cell line .

Copy Right, IJAR, 2016,. All rights reserved.

\section{Introduction:-}

Natural products with their inherent ability to interact with biological target, represent a significant source of inspiration for drug discovery and development [1]. Coumarins and structurally related acts as anticoagulant agent[2,3], inhibit replication of HIV and thus exhibit a therapeutic potential [4]. Coumarin is ministrant in curing cancer and presents a vital role in anti-inflammatory and antioxidant activities [5,6].

Coumarins are a large class of natural and/or synthetic products that have attracted interest because of their remarkable array of biological activities, usually associated to a low toxicity [7-14].

2,4-Diaryl-4H,5H-pyrano [3,2-c] benzopyran-5-ones, exhibits strong antiproliferative activities in MCF-7 breast carcinoma cells by a mechanisms that remains to be determined [15] and 1-benzopyrano-[3,4-b][1,4] benzothiazin6-ones, display interesting antioxidant, estrogenic -like effects in HePG2 and MCF-7 cells, respectively [16,17].

\section{Experimental:-}

General procedure for the synthesis of compounds 2 and 3:-

Anhydrous potassium carbonate $(0.69 \mathrm{~g}, 5.0 \mathrm{mmol})$ was added to a solution of 5-Hydroxy-4,7-dimethyl coumarin[18] $1(10 \mathrm{mmol})$ in anhydrous acetone $(150 \mathrm{ml})$, followed by refluxing until the solution became clear. Methyl bromoacetate or propargyl bromide $(20 \mathrm{mmol})$ was then dribbled into the mixture, and acetone $(10 \mathrm{ml})$ was added, the solution was refluxed for $5 \mathrm{~h}$. After completion of the reaction (monitored by TLC), the mixture was cooled to room temperature and diluted with water the precipitate was filtered and washed with water, left to dry and crystallized from ethanol.

Methyl (4,7-dimethyl coumarin-5-oxy) acetate 2:-

Yellowish powder yield 80\%;M.p. 160-162 ${ }^{\circ}$; IR $\left(\mathrm{cm}^{-1}\right)$ : $3055(\mathrm{CH}-\mathrm{Ar}), 2970(\mathrm{CH}-$ aliph.), $1710(\mathrm{C}=\mathrm{O}), 1680(\mathrm{C}=$ $\mathrm{O}) ;{ }^{1} \mathrm{H}$ NMR (DMSO-d $\left.\mathrm{d}_{6}\right) \delta(\mathrm{ppm}): 1.30,2.41,3.11\left(3 \mathrm{~s}, 9 \mathrm{H}, 3 \mathrm{CH}_{3}\right), 4.92\left(\mathrm{~s}, 2 \mathrm{H}, \mathrm{OCH}_{2}\right), 6.88,6.78,6.15(3 \mathrm{~s}, 3 \mathrm{H}$, C3-H, C6-H, C8-H, coumarin ring);MS:m/z=262 . 
4,7-Dimethyl-5-(prop-2-yn-1-yloxy) coumarin 3;-

Yellow powder. Yield 70\%; m.p. 180-182 ${ }^{\circ} \mathrm{C}$; IR $\left(\mathrm{cm}^{-1}\right) 3010(\mathrm{CH}-\mathrm{Ar}), 2910(\mathrm{CH}-\mathrm{aliph}),. 1700(\mathrm{C}=\mathrm{O}) ;{ }^{1} \mathrm{H}$ NMR $\left(\mathrm{DMSO}-\mathrm{d}_{6}\right) \delta(\mathrm{ppm}): 1.32,2.41\left(2 \mathrm{~s}, 6 \mathrm{H}, 2 \mathrm{CH}_{3}\right), 5.32\left(\mathrm{~s}, 2 \mathrm{H}, \mathrm{OCH}_{2}\right), 5.80(\mathrm{~s}, 1 \mathrm{H}, \mathrm{CH}), 6.81,6.77,6.11(3 \mathrm{~s}, 3 \mathrm{H}, \mathrm{C} 3-$ H, C6-H, C8-H, coumarin ring); MS: m/z=229 (M+1).

General procedure for the synthesis of compounds 4,5 and 6:-

Compound $1(5 \mathrm{mmol})$ and potassium carbonate $(5.5 \mathrm{mmol})$ were dissolved in DMF $(5 \mathrm{ml})$. The solution was stirred at room temperature for several minutes and then chloroacetone or ethyl chloroformate or 1,3-dibromopropane (5.2 $\mathrm{mmol}$ ) was added dropwise to the mixture. The solution was heated for $5 \mathrm{~h}$. After completion of the reaction (monitored by TLC), the mixture was cooled to room temperature and diluted with water. The precipitate was filtered and washed with water, left to dry and crystallized from ethanol.

\section{5-(Propenoneoxy)-4-7-dimethyl coumarin 4:-}

Brown crystal; yield 75\%; m.p. 180-182 ${ }^{\circ} \mathrm{C}$; IR $\left(\mathrm{cm}^{-1}\right) 3032$ (CH-Ar), 2988 (CH-aliph.), 1680, $1699(2 \mathrm{C}=\mathrm{O}) ;{ }^{1} \mathrm{H}$ NMR (DMSO-d $\left.\mathrm{d}_{6}\right) \delta(\mathrm{ppm}): 1.19,2.00,3.11\left(3 \mathrm{~s}, 9 \mathrm{H}, 3 \mathrm{CH}_{3}\right), 5.12\left(\mathrm{~s}, 2 \mathrm{H}, \mathrm{OCH}_{2}\right), 6.88,6.77,6.14(3 \mathrm{~s}, 3 \mathrm{H}, \mathrm{C} 3-\mathrm{H}$, C6-H, C8-H, coumarin ring); MS: m/z=246.

\section{5-(Propenoic acid)-4,7-dimethyl coumarinyl ester 5:-} Brown crystal; yield $60 \%$, m.p. $218-220^{\circ} \mathrm{C}$. IR( $\left(\mathrm{cm}^{-1}\right)$ : $3033(\mathrm{CH}-\mathrm{Ar}), 2900-2838(\mathrm{CH}-$ aliph. $), 1720,1690(2 \mathrm{C}=\mathrm{O})$ ${ }^{1} \mathrm{H}$ NMR (DMSO-d $\left.\mathrm{d}_{6}\right) \delta(\mathrm{ppm}): 2.11,2.84\left(2 \mathrm{~s}, 6 \mathrm{H}, 2 \mathrm{CH}_{3}\right) 3.88\left(\mathrm{t}, 3 \mathrm{H}, \mathrm{CH}_{2} \mathrm{CH}_{3}, \mathrm{~J}=7.12 \mathrm{~Hz}\right), 4.72\left(\mathrm{q}, 2 \mathrm{H}, \mathrm{CH}_{2} \mathrm{CH}_{3}, \mathrm{~J}\right.$ $=9.80 \mathrm{~Hz}), 6.80,6.78,6.12(3 \mathrm{~s}, 3 \mathrm{H}, \mathrm{C} 3-\mathrm{H}, \mathrm{C} 6-\mathrm{H}, \mathrm{C} 8-\mathrm{H}$, coumarin ring); MS: m/z = 246.

\section{5-(3-Bromopropoxy)-4,7-dimethyl coumarin 6:-}

Yellowish solid; yield 65\%; m.p. 100-102 ${ }^{\circ} \mathrm{C}$; IR $\left(\mathrm{cm}^{-1}\right)$ : $3055(\mathrm{CH}-\mathrm{Ar}), 2910-2850(\mathrm{CH}-\mathrm{aliph}),.\left(1690(\mathrm{C}=\mathrm{O}),{ }^{1} \mathrm{H}\right.$ NMR (DMSO-d $\left.{ }_{6}\right) \delta(\mathrm{ppm}): 1.12\left(\mathrm{~s}, 3 \mathrm{H}, \mathrm{CH}_{3}\right), 1.82-1.84\left(\mathrm{~m}, 2 \mathrm{H}, \mathrm{CH}_{2}\right), 2.40\left(\mathrm{~s}, 3 \mathrm{H}, \mathrm{CH}_{3}\right), 2.58\left(\mathrm{t}, 2 \mathrm{H}, \mathrm{CH}_{2}, \mathrm{~J}=\right.$ 7.0Hz)2.88(br.s, $\left.4 \mathrm{H}, 2 \mathrm{CH}_{2}\right), 4.18(\mathrm{t}, 2 \mathrm{H}, \mathrm{CH} 2, \mathrm{~J}=7.2 \mathrm{~Hz}), 3.48\left(\mathrm{~s}, 2 \mathrm{H}, \mathrm{OCH}_{2}\right), 6.83,6.70,6.14(3 \mathrm{~s}, 3 \mathrm{H}, \mathrm{C} 3-\mathrm{H}, \mathrm{C} 6-\mathrm{H}, \mathrm{C} 8-$ $\mathrm{H}$, coumarin ring); MS: $\mathrm{m} / \mathrm{z}=311$.

\section{5-(Trifloroacetate)-4,7-dimethyl coumarinyl ester 7:-}

Intimate mixture of trifloroacetic acid $(0.025 \mathrm{~mol}), 5$-hydroxy-4,7-dimethyl coumarin $1(0.025 \mathrm{~mol})$, benzene $(80 \mathrm{ml})$ and catalytic amount of concentrated sulfuric acid was refluxed for 8hrs the reaction mixture was then cooled, the crude product was crystallized out, filtered off and treated with dilute $\mathrm{NaHCO}_{3}$ solution. The crystals washed with water, dried and recrystallized from ethanol.

Brown powder; yield 60\%, m.p 220-222 ${ }^{\circ} \mathrm{C}$. IR $\left(\mathrm{cm}^{-1}\right): 3030$ (CH-Ar), 2984 (CH-aliph.); ${ }^{13} \mathrm{C}$ NMR (DMSO- $\left.\mathrm{d}_{6}\right): \delta$ (ppm): $15.10\left(\mathrm{CH}_{3}\right), 17.30\left(\mathrm{CH}_{3}\right), 116.70-138.51\left(\mathrm{C}-\mathrm{Ar}, \mathrm{CF}_{3}\right), 159.30(\mathrm{C}=\mathrm{O}), 163.81(\mathrm{C}=\mathrm{O})$, pyran ring); $\mathrm{MS}: \mathrm{m} / \mathrm{z}=286$.

\section{4, 11-Dimethylbenzopyrano[3,4-b][1,4]benzothiazin-2-one 8 .}

The 5-hydroxy coumarin derivative $\mathbf{1}(50 \mathrm{mmol})$ and 2-aminothiophenol $(60 \mathrm{mmol})$ were added to $(20 \mathrm{ml})$ of DMSO and heated to $140^{\circ} \mathrm{C}$ for $12 \mathrm{~h}$. On cooling at room temperature the product was filtered under vacuum,recrystallization from (DMF) gave green powder; yield $90 \%$; m.p. $360^{\circ} \mathrm{C}$; IR $\left(\mathrm{cm}^{-1}\right) .3335(\mathrm{NH}), 3010$ (CH-Ar), 2980 (CH-aliph.), $1678(\mathrm{C}=\mathrm{O}) ;{ }^{1} \mathrm{H}$ NMR (DMSO-d $\left.{ }_{6}\right) \delta(\mathrm{ppm}): 1.80\left(\mathrm{~s}, 3 \mathrm{H}, \mathrm{CH}_{3}\right), 2.41\left(\mathrm{~s}, 3 \mathrm{H}, \mathrm{CH}_{3}\right)$, 7.72-7.23 (m, 6H, Ar-H), $8.89\left(\mathrm{~s}, 1 \mathrm{H}, \mathrm{NH}\right.$ exchangeable with $\left.\mathrm{D}_{2} \mathrm{O}\right) ; \mathrm{MS}: \mathrm{m} / \mathrm{z}=294(\mathrm{M}-1)$; Anal. Calcd.For : $\mathrm{C}_{17} \mathrm{H}_{13} \mathrm{NSO}_{2}$ (295): C, 69.15; H, 4.40; N, 4.74, S, 10.84; Found: C, 69.20; H, 4.11; N, 4.30; S, 11.00.

\section{4,9-Dimethyl-6,8-di(2-thienyl)pyrano[2,3-h) coumarin 9:-}

A mixture of chalcone $(0.01 \mathrm{~mol})$ and compound $\mathbf{1}(0.01 \mathrm{~mol})$ were dissolved in ethanol $(30 \mathrm{ml})$ and piperidine $(8 \mathrm{ml})$ was added. The resulting solution was filtered off and recrystallized from ethanol gave brown powder; yield 62\%; m.p. 218-220 ${ }^{\circ} \mathrm{C}$; IR $\left(\mathrm{cm}^{-1}\right)$ : 3055 (CH-Ar), $2980\left(\mathrm{CH}-\mathrm{aliph}\right.$.) $1690(\mathrm{C}=\mathrm{O}), 1600(\mathrm{C}=\mathrm{C}) ;{ }^{1} \mathrm{H}$ NMR (DMSO-d $\left.{ }_{6}\right)$ $\delta(\mathrm{ppm}): 1.35,2.41\left(2 \mathrm{~s}, 6 \mathrm{H}, 2 \mathrm{CH}_{3}\right), 4.70,4.10(2 \mathrm{~d}, 2(\mathrm{CH})$, pyran ring, $\mathrm{J}=2 \mathrm{~Hz}), 6.80-7.88(\mathrm{~m}, 8 \mathrm{H}, \mathrm{Ar}-\mathrm{H}) . \mathrm{MS}: \mathrm{m} / \mathrm{z}=$ 392 . 


\section{5-[(2-oxo-2H-chromen-3-yl) oxy[-4,7-dimethyl coumarin 10;-}

Equimolar amounts $(10 \mathrm{mmol})$ of the ester 2 and the proper 5-bromo salicyladehydewas heated without solvent at $180^{\circ} \mathrm{C}$ for $1 \mathrm{~h}$. then the mixture was left to cool. The solid product that formed was crystallized from ethanol to give compound 10, brown crystal; yield 65\%; m.p. 140-142 ${ }^{\circ} \mathrm{C}$; IR $\left(\mathrm{cm}^{-1}\right)$ : $3032(\mathrm{CH}-\mathrm{Ar}), 2977$ (CH-aliph.), 1720, 1691 $(2 \mathrm{C}=\mathrm{O}), 1167(\mathrm{C}-\mathrm{O}-\mathrm{C}) ;{ }^{1} \mathrm{H}$ NMR $\left(\mathrm{DMSO}-\mathrm{d}_{6}\right) \delta(\mathrm{ppm}): 1.28,1.80\left(2 \mathrm{~s}, 6 \mathrm{H}, 2 \mathrm{CH}_{3}\right), 6.80,6.78,6.13\left(3 \mathrm{~s}, 3 \mathrm{H}, \mathrm{C}_{3}-\mathrm{H}\right.$, $\mathrm{C}_{6}-\mathrm{H}, \quad \mathrm{C}_{8}-\mathrm{H}$,coumarinring), $\quad 7.22-7.57 \quad(\mathrm{~m}, \quad 3 \mathrm{H}, \quad$ bromocoumarin $\quad$ ring $), \quad 8.12 \quad\left(\mathrm{~s}, \quad 1 \mathrm{H}, \quad \mathrm{C}_{4}-\mathrm{H}\right)$, (bromocoumarin);MS:m/z=413.

\section{5- [1H-benzimidazol-2-yl)-methoxy]-4,7-dimethyl coumarin 11:-}

A mixture of ester $2(3 \mathrm{mmol})$ and 1,2-phenylene-diamine $(3 \mathrm{mmol})$ was heated without solvent at $180^{\circ} \mathrm{C}$ for $2 \mathrm{~h}$. then the mixture was left to cool. The solid product that formed was crystallized from ethanol to give 11, brown solid; yield $55 \%$; m.p. $220-222{ }^{\circ} \mathrm{C}$;

IR $\left(\mathrm{cm}^{-1}\right), 3210(\mathrm{NH}), 3032(\mathrm{CH}-\mathrm{Ar}), 2982-2880\left(\mathrm{CH}\right.$-aliph.), $1690(\mathrm{C}=\mathrm{O}), 1624(\mathrm{C}=\mathrm{N}){ }^{1} \mathrm{H}$ NMR (DMSO-d 6$) \delta$ (ppm): 1.19, $2.32\left(2 \mathrm{~s}, 6 \mathrm{H}, 2 \mathrm{CH}_{3}\right), 4.57\left(\mathrm{~s}, 2 \mathrm{H}, \mathrm{OCH}_{2}\right), 6.83,6.78,6.15\left(3 \mathrm{~s}, 3 \mathrm{H}, \mathrm{C}_{3}-\mathrm{H}, \mathrm{C}_{6}-\mathrm{H}, \mathrm{C}_{8}-\mathrm{H}\right.$,coumarin ring) 7.80-7.55m, $4 \mathrm{H}, \mathrm{Ar}-\mathrm{H}), 9.98\left(\mathrm{~s}, 1 \mathrm{H}, \mathrm{NH}\right.$, exchangeable with $\mathrm{D}_{2} \mathrm{O}$ ); $\mathrm{MS}: \mathrm{m} / \mathrm{z}=320$; Anal.Calcd. For: $\mathrm{C}_{19} \mathrm{H}_{16} \mathrm{~N}_{2} \mathrm{O}_{3}$ (320): C, 71.25; H, 5.00; N, 8.75; Found: C, 71.00; H, 5.18; N, 9.00.

\section{[(4,7-dimethycoumarin-5-yloxy)]acetohydrazide 12:-}

To a suspension of the compound $\mathbf{2}(10 \mathrm{mmol})$ in absolute ethanol $(25 \mathrm{ml})$, was added hydrazine hydrate $(20 \mathrm{mmol}$, 98\%) the mixture was stirred at room temperature for $2 \mathrm{~h}$, and then the solid precipitate so formed was filtered and crystallized from ethanol to afford the hydrazide12, white solid; yield $90 \%$; m.p./ $210-212{ }^{\circ} \mathrm{C}$; IR $\left(\mathrm{cm}^{-1}\right): 3333,3277$ $\left(\mathrm{NH}_{2}\right), 3250(\mathrm{NH}) 3020(\mathrm{CH}-\mathrm{Ar}), 2980-2880(\mathrm{CH}-\mathrm{aliph}),. 1690(\mathrm{C}=\mathrm{O}), 1660(\mathrm{C}=\mathrm{O} \text { hydrazide })^{1}{ }^{1} \mathrm{H}$ NMR $\left(\mathrm{DMSO}-\mathrm{d}_{6}\right) \delta(\mathrm{ppm}): 1.30,1.81\left(2 \mathrm{~s}, 6 \mathrm{H}, 2 \mathrm{CH}_{3}\right), 4.27$ (br., $2 \mathrm{H}, \mathrm{NH}_{2}$, exchangeable with $\left.\mathrm{D}_{2} \mathrm{O}\right), 4.83\left(\mathrm{~s}, 2 \mathrm{H}, \mathrm{OCH}_{2}\right)$, 6.80, 6.77, 6.13 (3s, 3H, C3-H,C6-H,C8-H,coumarin ring), 9.11 (s, 1H, CONH, exchangeable with $\mathrm{D}_{2} \mathrm{O}$ ); Anal. Calcd. For: $\mathrm{C}_{13} \mathrm{H}_{14} \mathrm{~N}_{2} \mathrm{O}_{4}$ (262): C, 59.54; H, 5.34; N, 10.68; Found : C, 60.00; H, 5.00; N, 10.44.

\section{5-[(3-oxo-2,3-dihydro-1H-pyrazol-4-yl) oxy]-4, 7-dimethyl coumarin 13:-}

To a solution of the acetohydrazide12 $(5 \mathrm{mmol})$ in DMF $(15 \mathrm{~mL})$, triethylorthoformate $(6 \mathrm{mmol})$ was added and heated under reflux for $8 \mathrm{~h}$. the reaction mixture was filtered while hot, the solvent was removed under reduced pressure, and the solid obtained was dried and crystallized from ethanol to afford 13; brown crystal; yield 65\%; m.p. 162-164 ${ }^{\circ} \mathrm{C}$; IR $\left(\mathrm{cm}^{-1}\right): 3299,3218(2 \mathrm{NH}), 1700(\mathrm{C}=\mathrm{O}), 1688(\mathrm{C}=\mathrm{O}), 1145(\mathrm{C}-\mathrm{O}-\mathrm{C}) ;{ }^{1} \mathrm{H}$ NMR (DMSO-d 6 ) $\delta$ (ppm): 1.22, $2.28\left(2 \mathrm{~s}, 6 \mathrm{H}, 2 \mathrm{CH}_{3}\right) 6.82,6.73,6.13(3 \mathrm{~s}, 3 \mathrm{H}, \mathrm{C} 3-\mathrm{H}, \mathrm{C} 6-\mathrm{H}, \mathrm{C} 8-\mathrm{H}$,coumarin ring), $8.66(\mathrm{~s}, 1 \mathrm{H}, \mathrm{CH}$ pyrazol) $9.50\left(\mathrm{~s}, 1 \mathrm{H}, \mathrm{NH}\right.$, exchangeable with $\left.\mathrm{D}_{2} \mathrm{O}\right), 10.05\left(\mathrm{~s}, 1 \mathrm{H}, \mathrm{NHCO}\right.$, exchangeable with $\left.\mathrm{D}_{2} \mathrm{O}\right) \mathrm{MS}: \mathrm{m} / \mathrm{z}=271$ (M-1); Anal. Calcd.for: $\mathrm{C}_{14} \mathrm{H}_{12} \mathrm{~N}_{2} \mathrm{O}_{4}$ (272): C, 61.76; H, 4.41; N, 10.29; Found: C, 61.50; H, 4.44; N, 10.18 .

\section{N-p-chlorobenzylidine (4,7-dimethyl coumarin-5-yl oxy) acetohydrazide 14:-}

A solution of acid hydrazide $12(2 \mathrm{mmol})$ in methanol $(10 \mathrm{ml})$ and p-chlorobenzaldehyde $(2 \mathrm{mmol})$ was refluxed for $8 \mathrm{~h}$. After the reaction was completed, the light yellow Schiff base coms out. This was collected by filtration. The resulting solid was crystallized from methanol to afford 14; yield 85\%; m.p. $250-252{ }^{\circ} \mathrm{C} \mathrm{IR}\left(\mathrm{cm}^{-1}\right)$ : $3312(\mathrm{OH}), 3233$ (NH), 3010 (CH-Ar) 2988 (CH-aliph.), 1690 (C= O),

$1660\left(\mathrm{C}=\mathrm{O}\right.$, amide) ${ }^{1} \mathrm{H}$ NMR (DMSO-d $\left.\mathrm{d}_{6}\right) \delta(\mathrm{ppm}): 1.24,2.28\left(2 \mathrm{~s}, 6 \mathrm{H}, 2 \mathrm{CH}_{3}\right), 4.58\left(\mathrm{~s}, 2 \mathrm{H}, \mathrm{OCH}_{2}\right) .6 .80,6.74,6.10$ $\left(3 \mathrm{~s}, 3 \mathrm{H}, \mathrm{C}_{3}-\mathrm{H}, \mathrm{C}_{6}-\mathrm{H}, \mathrm{C}_{8}-\mathrm{H}\right.$, coumarin ring), 8.22, $7.78(2 \mathrm{~d} 4 \mathrm{H}, \mathrm{Ar}-\mathrm{H}, \mathrm{J}=4.8 \mathrm{~Hz}), 9.80(\mathrm{~s}, 1 \mathrm{H}, \mathrm{NH}$, exchangeable with $\mathrm{D}_{2} \mathrm{O}$ ).

\section{[(4,7-dimethylcoumarin-5-yloxy)-N-(2-p-chlorophenyl thiazolidin-4-one-3yl)] acetamide15:-}

A solution of $\mathbf{1 4}(1 \mathrm{mmol})$ in dry benzene $(10 \mathrm{ml})$ was refluxed for $6 \mathrm{~h}$. withthioglycolic acid $(3 \mathrm{mmol})$. The reaction mixture was cooled, the solvent was removed under reduced pressure; the residue was neutralized with $10 \%$ sodium carbonate solution. the solid obtained was filtered, dried and wash with several solvent, it insoluble in any solvent; white powder, yield 55\%; m.p. $>360{ }^{\circ} \mathrm{C}$; IR $\left(\mathrm{cm}^{-1}\right) 3315(\mathrm{OH}), 3218(\mathrm{NH}), 3065(\mathrm{CH}-\mathrm{Ar}), 2835(\mathrm{CH}-$ aliph.). 1660, $1650\left(\mathrm{C}=\mathrm{O}\right.$, amid groups) $1690(\mathrm{C}=\mathrm{O})$; ${ }^{1} \mathrm{H}$ NMR $\left(\mathrm{DMSO}-\mathrm{d}_{6}\right) \delta(\mathrm{ppm}) .1 .20,2.44\left(2 \mathrm{~s}, 6 \mathrm{H}, 2 \mathrm{CH}_{3}\right), 4.92(2 \mathrm{~s}, 2 \mathrm{H}, \mathrm{O}-$ $\left.\mathrm{CH}_{2}\right), 5.57\left(\mathrm{~s}, 2 \mathrm{H}, \mathrm{s}-\mathrm{CH}_{2}\right) 6.13(\mathrm{~s}, 1 \mathrm{H}, \mathrm{CH}), 6.83,6.77,6.18(3 \mathrm{~s}, 3 \mathrm{H}, \mathrm{C} 3-\mathrm{H}, \mathrm{C} 6-\mathrm{H}, \mathrm{C} 8-\mathrm{H}$, coumarin ring), 8.58, $7.41(2 \mathrm{~d}, 4 \mathrm{H}, \mathrm{Ar}-\mathrm{H} ; \mathrm{J}=4.11 \mathrm{~Hz}, \mathrm{~J}=2.88 \mathrm{~Hz}), 12.85\left(\mathrm{~s}, 1 \mathrm{H}, \mathrm{NH}\right.$, exchangeable with $\left.\mathrm{D}_{2} \mathrm{O}\right)$; Anal. Calcd.for: $\mathrm{C}_{22} \mathrm{H}_{19} \mathrm{ClN}_{2} \mathrm{SO}_{5}(458.5)$ : C, 57.57; H, 4.14; N, 6.10; S, 6.97; Found: C, 57.70; H, 4.00; N, 6.32; S, 7.00. 
Ethyl-5-[(4,7-dimethyl coumarin-5-yl oxy) acetyl] hydrazine carboxylate 16:-

A mixture of acid hydrazide $12(3 \mathrm{mmol})$ and ethyl chloroformate $(4 \mathrm{mmol})$ in pyridine $(20 \mathrm{ml})$ was refluxed for $8 \mathrm{~h}$. the residue was triturated with water, filtered the solid obtained was dried and crystallized from ethanol, brown powder; 88\% yield; m.p. $260-262{ }^{\circ} \mathrm{C}$; IR $\left(\mathrm{cm}^{-1}\right)$ : 3320, $3280(2 \mathrm{NH}), 3055(\mathrm{CH}-\mathrm{Ar}) 2920$ (CH-aliph.), 1710, 1690, $1660(3 \mathrm{C}=\mathrm{O}), ;{ }^{1} \mathrm{H}$ NMR $\left(\mathrm{DMSO}-\mathrm{d}_{6}\right) \delta(\mathrm{ppm}): 1.20,2.61\left(2 \mathrm{~s}, 6 \mathrm{H}, 2 \mathrm{CH}_{3}\right) 1.23$ (t. $\left.3 \mathrm{H}, \mathrm{CH}_{2} \mathrm{CH}_{3} \mathrm{~J}=2.5 \mathrm{~Hz}\right) 4.21(\mathrm{q}$, $\left.2 \mathrm{H}, \mathrm{CH}_{2} \mathrm{CH}_{3}, \mathrm{~J}=7.00 \mathrm{~Hz}\right), 4.80\left(\mathrm{~s}, 2 \mathrm{H}, \mathrm{OCH}_{2}\right) 7.00(\mathrm{~s}, 1 \mathrm{H}, \mathrm{NH})$ exchangeable with $\left.\mathrm{D}_{2} \mathrm{O}\right) 6.83,6.78,6.14(3 \mathrm{~s}, 3 \mathrm{H}$, C3-H, C6-H, C8-H, coumarin ring), 10.84 (s, 1H,CONH, exchangeablewith $\mathrm{D}_{2} \mathrm{O}$ ).

Anal.Calcd. for: $\mathrm{C}_{16} \mathrm{H}_{18} \mathrm{~N}_{2} \mathrm{O}_{6}$ (334): C, 57.48; H, 5.38; N, 8.38; Found : C, 57.50; H, 5.31; N, 8.50.

4-[4,7-dimethyl coumarin-5-yl oxy)]pyrazolidin-3,5-dione 17:-

A hydrazine carboxylate16 (1 mmol) was refluxed in absolute ethanol $(10 \mathrm{ml})$ containing sodium metal (1 mmol) for $6 \mathrm{~h}$. the reaction mixture was cooled, the residue was triturated with water, filtered, the solid obtained was dried and wash with several solvent and crystallized from DMF, black powder; yield 59\%; m.p. $>360^{\circ} \mathrm{C}$; IR $\left(\mathrm{cm}^{-1}\right): 3380$ (2NH), 3010 (CH-Ar), 2880 (CH-aliph.), 1690, 1670, 1660 (3C=O), 1145 (-C-O-C-). ; ${ }^{1} \mathrm{H}$ NMR (DMSO-d 6 ) $\delta$ (ppm): 1.19, $2.33\left(2 \mathrm{~s}, 6 \mathrm{H}, 2 \mathrm{CH}_{3}\right), 5.80$ (s, 1H, CH-pyrazole), 6.83, 6.72, 6.11 (3s, 3H, C3-H, C6-H, C8-H, coumarin ring), $9.18\left(\mathrm{~s}, 2 \mathrm{H}, 2 \mathrm{NH}\right.$, exchangeable with $\mathrm{D}_{2} \mathrm{O}$ ). Anal.Calcd.for: $\mathrm{C}_{14} \mathrm{H}_{12} \mathrm{~N}_{2} \mathrm{O}_{5}(288)$ : C, 58.33; H, 4.16; N, 9.72; Found: C, 58.71; H, 4.33; N, 10.00 .

\section{5-[(2-Methyl-5-(methylthio)-3-oxo-2,3-dihydro-1H-pyrazol-4-yl)oxy]-4,7-dimethyl coumarin 18;-}

To a solution of the acetohydrazide12 $(5 \mathrm{mmol})$, in absolute ethanol $(50 \mathrm{ml})$, sodium ethoxide $(15 \mathrm{mmol})$ was added followed by drop-wise addition of carbon disulfide $(5 \mathrm{mmol})$ with contineous stirring in an ice - cold water bath at $0-5^{\circ} \mathrm{C}$. After complete addition, the mixture was stirred at room temperature for $30 \mathrm{~min}$. and methyl iodide (20 $\mathrm{mmol}$ ) was dropped over a period of $20 \mathrm{~min}$., then the reactor was fitted with reflux condenser and heated atboiling for $1 \mathrm{~h}$. After cooling, the crystalline deposits were collected by filtration, washed with cold ethanol and crystallized fromethanol to afford 18, white crystal; 50\% yield; m.p. 260-262 ${ }^{\circ} \mathrm{C}$; IR $\left(\mathrm{cm}^{-\mathbf{1}}\right): 3250(\mathrm{NH}), 3055(\mathrm{CH}-\mathrm{Ar}), 2910$ (CH-aliph.), 1660, $1688(2 \mathrm{C}=\mathrm{O})$, pyrazolinone and coumarin), $1145(-\mathrm{C}-\mathrm{O}-\mathrm{C}) ; ;{ }^{1} \mathrm{H}$ NMR (DMSO- $\left.\mathrm{d}_{6}\right) \delta$ (ppm):1.06, $2.32\left(2 \mathrm{~s}, 6 \mathrm{H}, 2 \mathrm{CH}_{3}\right) ; 2.61\left(\mathrm{~s}, 3 \mathrm{H}, \mathrm{SCH}_{3}\right), 3.43\left(\mathrm{~s}, 3 \mathrm{H}, \mathrm{NCH}_{3}\right), 6.99,6.78,6.13\left(3 \mathrm{~s}, 3 \mathrm{H}, \mathrm{C}_{3}-\mathrm{H}, \mathrm{C}_{6}-\mathrm{H}, \mathrm{C}_{8}-\right.$ $\mathrm{H}$, coumarin ring), $9.18\left(\mathrm{~s}, 1 \mathrm{H}, \mathrm{NH}\right.$, exchangeable with $\mathrm{D}_{2} \mathrm{O}$ ); $\mathrm{MS}: \mathrm{m} / \mathrm{z}=334$; Anal. Calcd.for: $\mathrm{C}_{16} \mathrm{H}_{18} \mathrm{~N}_{2} \mathrm{SO}_{4}(334)$ : C, 57.48; H, 5.38; N, 8.38; S, 9.58. Found: C, 57.50; H, 5.50; N, 8.11, S, 10.00.

\section{Results and Discussion:-}

5-Hydroxy-4,7-dimethyl coumarin 1 [18] reacted with methyl bromoacetate,propargyl bromide,chloroacetone, ethyl chloroformate, and 1,3-dibromopropane in the presence of anhydrous potassium carbonate in dry acetone or DMF to give the corresponding derivatives $\mathbf{2 , 3 , 4 , 5}$ and $\mathbf{6}$. The obtained spectra data were in accordance with the proposed structure. The appearance of new stretching band and disappearance of characteristic peak for $\mathrm{OH}$ and their proton ${ }^{1} \mathrm{H}$ NMR spectra also lacked signal characteristic of $\mathrm{OH}$ proton and showed new peaks at 4.92-5.82 ppm (integration for two protons) attributed to $\mathrm{OCH}_{2}$ protons for compounds $2,3,4$ and 6.5-(Trifloroacetate)-4,7-dimethyl coumarinyl ester 7 was synthesized by the formation of an ester linkage between 5-hydroxy coumarin derivative 1 and trifloroacetiaacid in a strong acidic medium. This mechanistic route first involves protonation of the carboxylic acid, which activates it for reaction with non protonated phenol to yield a tetrahedral intermediate that by decomposition; produces the product [19]. 


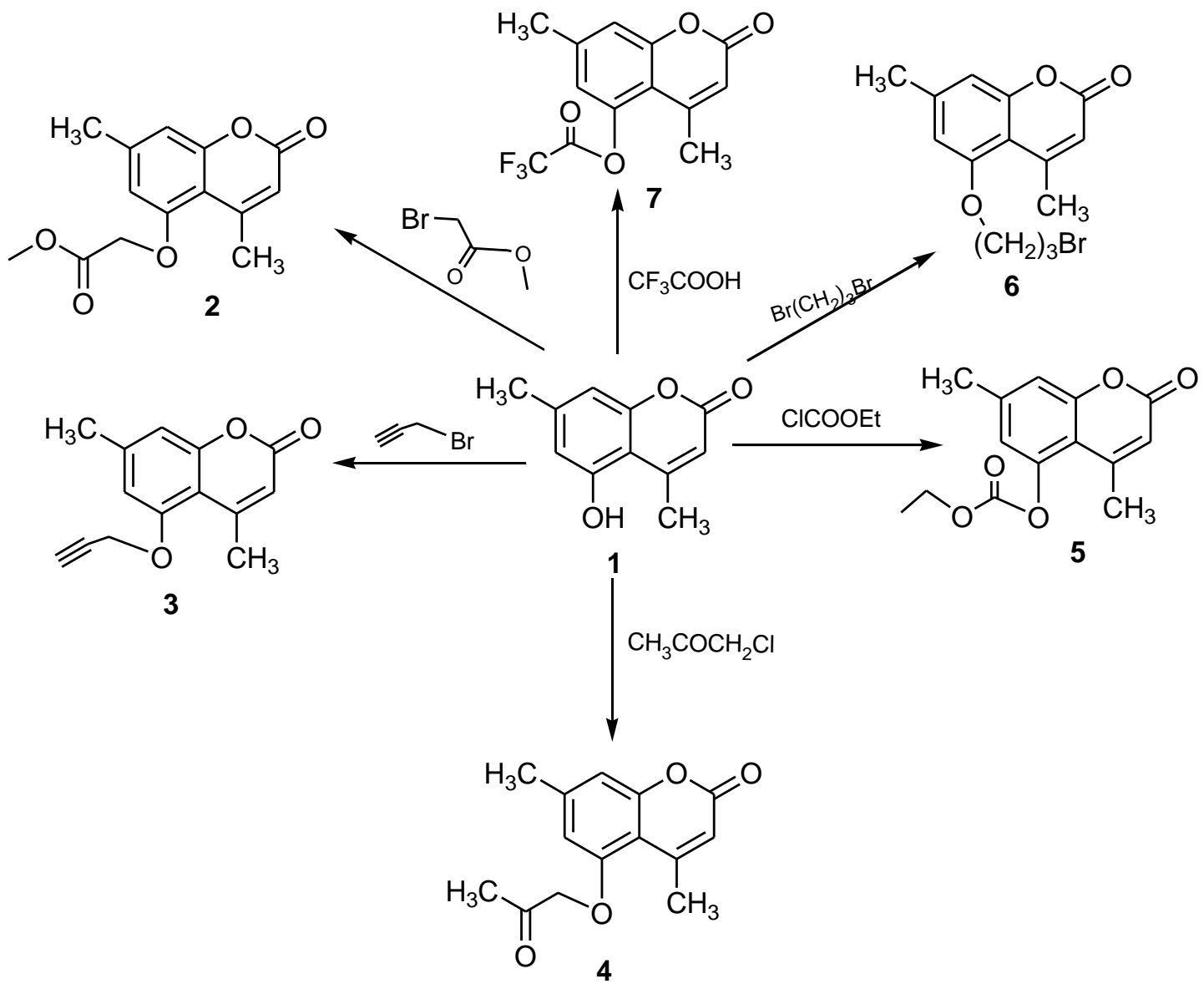

(Scheme 1)

The 4,11-dimethylbenzopyrano[3,4-b]benzothiazin-2-one 8 was prepared as shown in ( scheme 2). Thequadricyclic system was synthesized according to the method of Tabakovic [17,20].The addition of 2-aminothiophenol on the substituted- 5-hydroxycoumarin $\mathbf{1}$ was made in polar aprotic solvent (DMSO). This addition was accompanied by the elimination of one molecule of water and conducted to a non-isolable enaminone intermediate [16]. Subject to a nucleophilic attack at the 6-position of the coumarin, the bis(o-aminophenyl) disulfide motif was cleaved and the enaminone led to the desired product $\mathbf{8}$ by an interamolecularcyclization. The structure was assigned from spectral data (see experimental).

5-Hydroxy-4,7-dimethyl coumarin1 reacted well with chalcone to give pyranocoumarin9.

Initially the reaction was carried using piperidineas catalyst and ethanol as the solvent under reflux condition. A proposed mechanism for the tandem reaction is shown in scheme 2. Probably the first step is the Michael addition of 5 -hydroxy coumarin to the $\alpha, \beta$-unsaturated ketone which gave the intermediates $\left(8^{\prime}, 8^{\prime \prime}\right)$. The intermediate afforded the desired pyranocoumarin through intramolecualrcyclizatoin by removal of water.

The structure of compound 9 was proved by spectral data. IR showed the absence of $\mathrm{OH}$ group and ${ }^{1} \mathrm{H}$ NMR spectrum showed two doubled at $4.70(\mathrm{~J}=2.0 \mathrm{~Hz})$ and at $4.10(\mathrm{~J}=2.0 \mathrm{~Hz})$ integrating for one proton each, which were assigned to $\mathrm{H}-3$ and $\mathrm{H}-4$ pyran ring. 


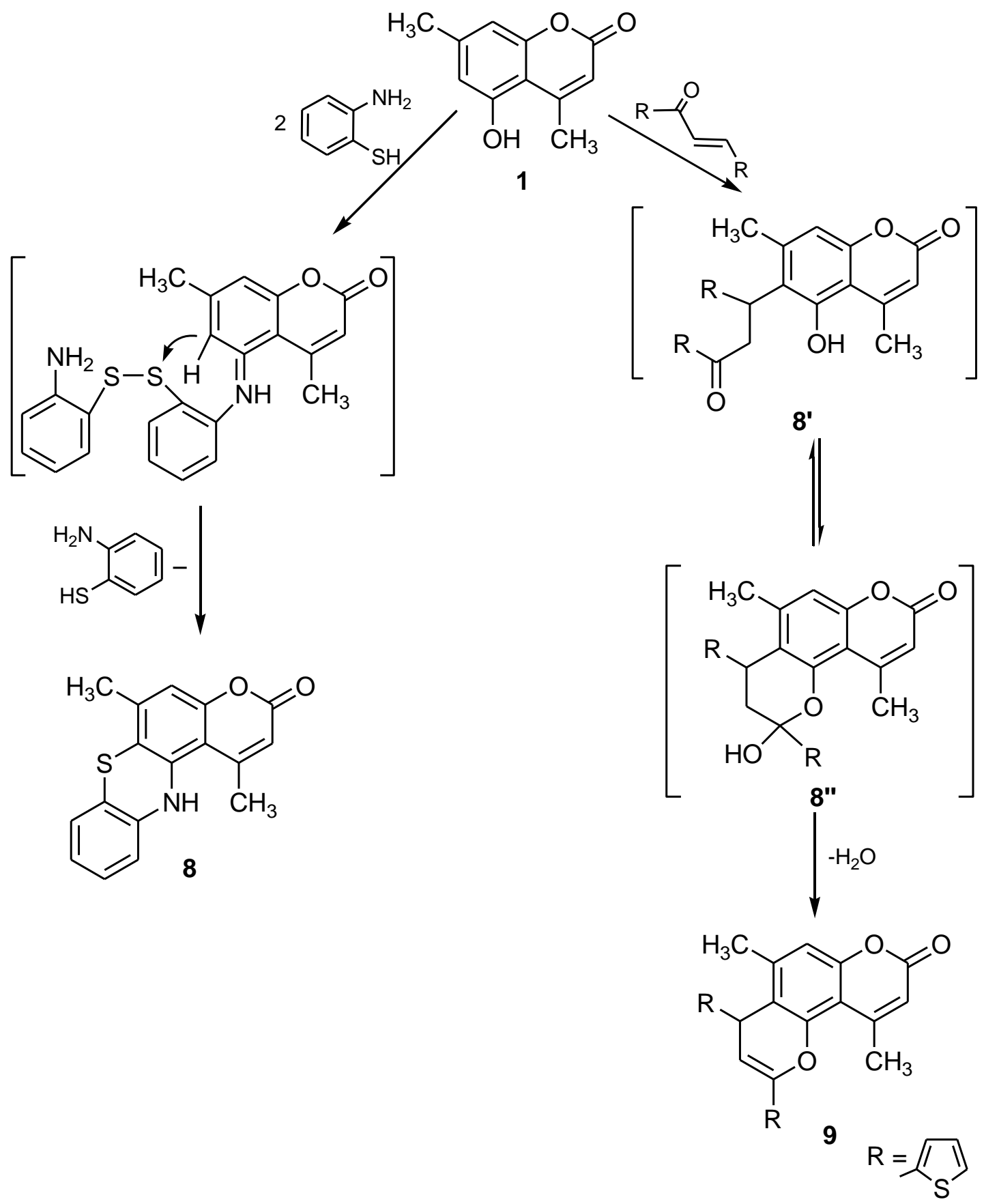

(Scheme 2)

Knoevenagel reaction of $\alpha$-active methylene esters with ortho-hydroxy-aldehyde was reported as facile synthesis of condensed $\alpha$-pyranone and coumarin [21]. Thermal condensation of ester 2 with 5-bromo salicylaldehyde was carried out to prepare the corresponding 5-[2-oxo-2H chromen-3-yl)oxy]-4,7-dimethyl coumarin10 (scheme 3). IR spectrum shows evidences for this cyclization by exhibiting two absorption bands at 1720 and $1691 \mathrm{~cm}^{-1}$ corresponding to pyranone and coumarin carbonyls, respectively. 5-[1H-Benzimidazol-2-yl)-methoxy]-4,7-dimethyl coumarin 11 was prepared by thermal condensation reaction fo 1,2-phenylenediamine with ester 2 in $64 \%$ yield. This reaction was carried out thermally in absence of solvent . The structure of compound $\mathbf{1 1}$ was inferred from its IR, ${ }^{1} \mathrm{H}$ NMR spectral data and elemental microanalysis.. 


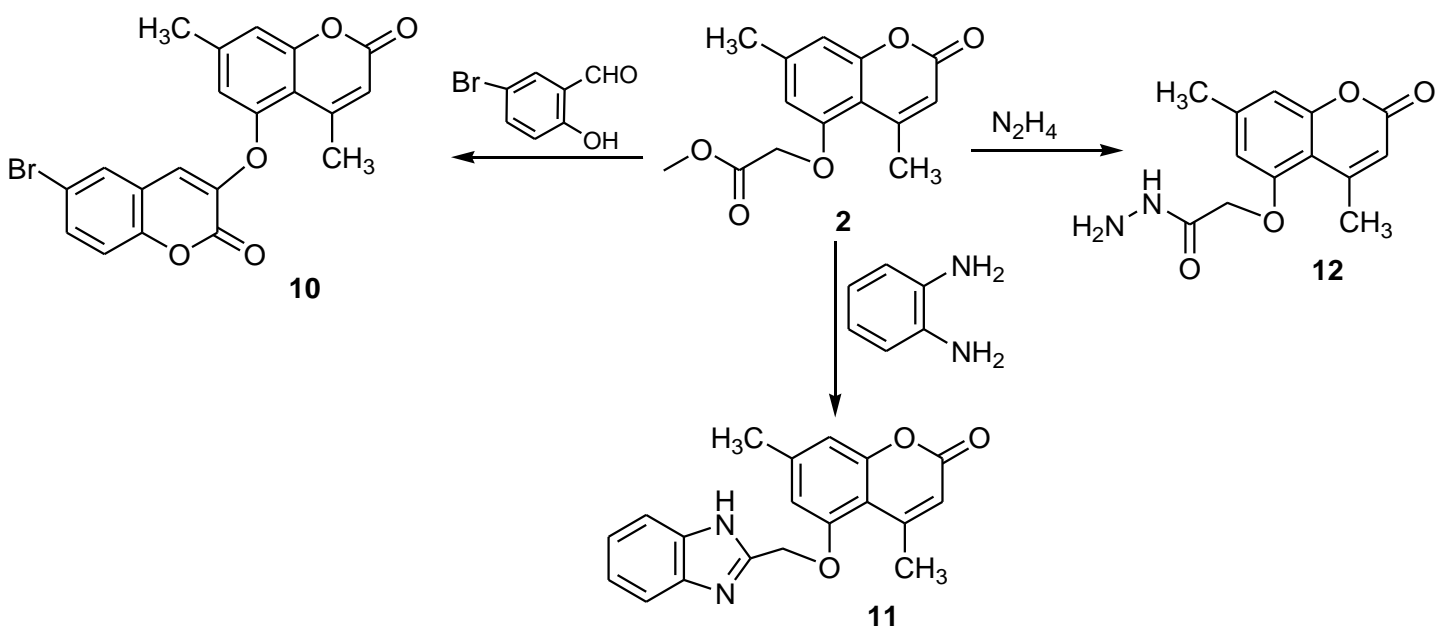

(Scheme 3)

The acetohydrazide 12 was obtained from the hydrazinolysis of ester $\mathbf{2}$ as a key intermediate in $90 \%$ yield.

Thermal cyclization of acetohydrazide12 with triethylorthoformate, smoothly afforded pyrazolinone13 the spectral data of the product13 revealed the disappearance of both $\mathrm{NH}_{2}$ and $\mathrm{OCH}_{2}$ groups, indicating their involvement in cyclization process. The reaction of hydrazide12 with 4-chlorobenzaldehyde was carried out in the presence of piperidine in boiling ethanol gave compound14.

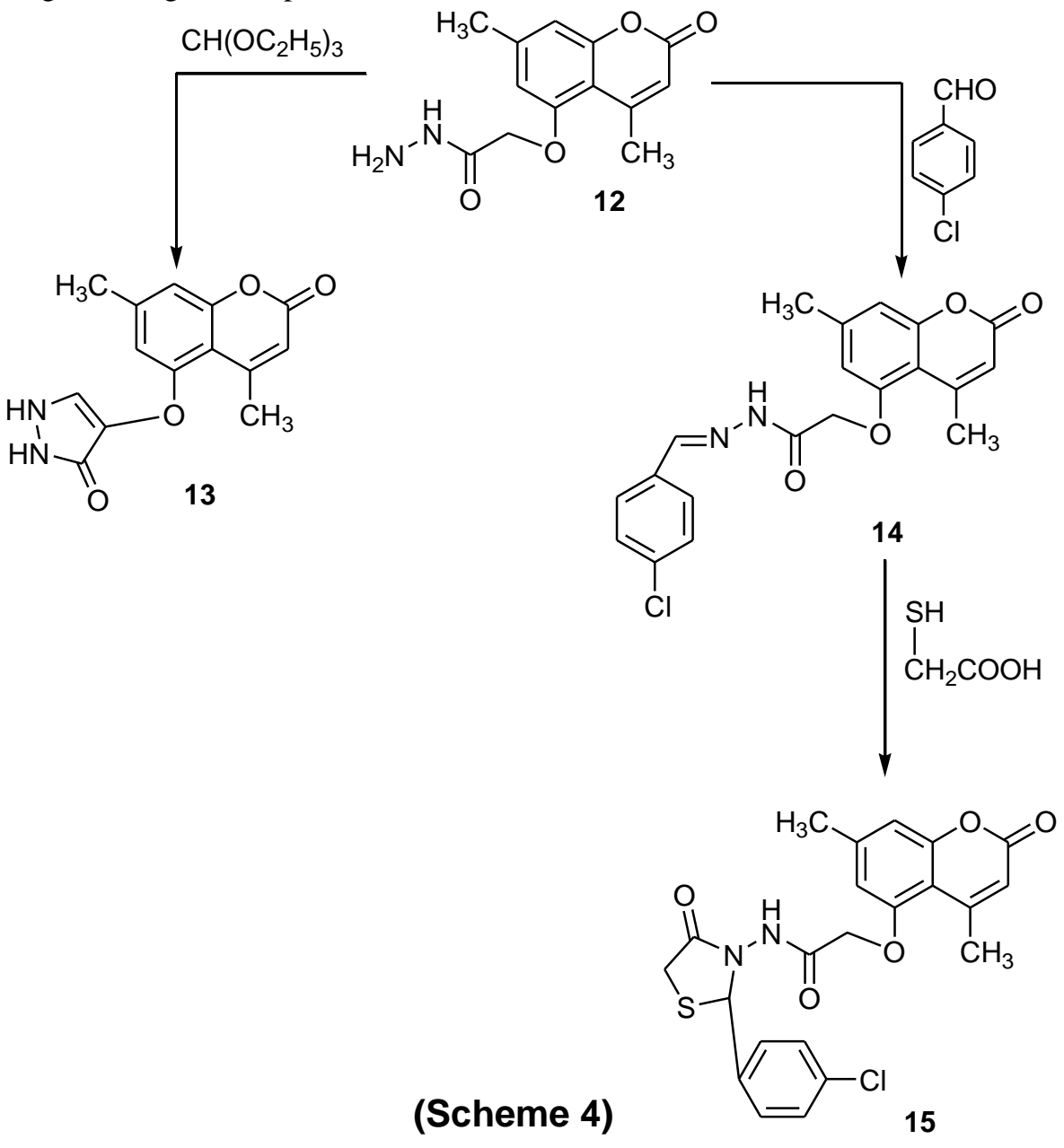


Compound 14 was subjected to cyclization via reaction with thioglycolic acid to afford [(4,7-dimethyl coumarin-5yloxy)-N-(2-p-chlorophenyl thiazolidin-4-on-3yl)] acetamide15. (scheme 4). ${ }^{1} \mathrm{H}$ NMR spectrum of compound 15, revealed presence of $\left(-\mathrm{OCH}_{2}-\right)$ group at $\delta 4.92$ and $\delta 5.57 \mathrm{ppm}$ due $\left(\mathrm{S}_{-} \mathrm{CH}_{2}\right)$.

On the other hand, the reaction of $\mathbf{1 2}$ with ethyl chloroformate in anhydrous pyridine gave ethyl-5-[(4,7-dimethyl coumarin-5-yl oxy) acetyl] hydrazine carboxylate $\mathbf{1 6}$ in $88 \%$ yield, which was subjected to cyclization with sodium ethoxide in boiling ethanol to afford 4[(4,7-dimethyl coumarin-5-yloxy) pyrazolidin-3,5-dione 17in 59\% yield (Scheme 5). ${ }^{1} \mathrm{H}$ NMR spectrum of $\mathbf{1 6}$ shows the existence of ethyl set of protons due to $\left(\mathrm{COOC}_{2} \mathrm{H}_{5}\right)$ group as triplet at $\delta 1.23$ and quartet at $\delta 4.21 \mathrm{ppm}$.<smiles>CCOC(=O)NNC(=O)COc1cc(C)cc2oc(=O)cc(C)c12</smiles>

(Scheme 5)

While, ${ }^{1} \mathrm{H}$ NMR spectrum of $\mathbf{1 7}$ revealed the disappearance of both $\mathrm{OC}_{2} \mathrm{H}_{5}$ and $\mathrm{OCH}_{2}$ groups, indicating their involvement in cyclization process.

5-[(2-methyl-5-(methylthio)-3-oxo-2,3-dihydro-1H pyrazol-4-yl]oxy]-4,7-dimethyl coumarin 18 was characterized as the product obtained when hydrazide 12 was treated with carbon disulfide and excess amount of methyl iodide. ${ }^{1} \mathrm{H}$ NMR spectrum of compound 18, revealed presence of two types of methyl groups at $\delta 2.61 \mathrm{ppm}$ due to $\left(\mathrm{SCH}_{3}\right)$ and $\delta 3.43 \mathrm{ppm}$ due to $\left(\mathrm{NCH}_{3}\right)$ and absence of specific signal for $\left(\mathrm{OCH}_{2}\right)$. The characteristic IR stretching bands at 1688 and $1660 \mathrm{~cm}^{-1}$ shows the occurrence of $\mathrm{C}=\mathrm{O}$ groups due to pyrazolinone and coumarin systems. Formation of compound $\mathbf{1 8}$ is though to be through the expected intermediate $\mathbf{1 7}$ ' which was not isolated.

\section{Biological Testing:-}

\section{Cell line:-}

Hepatocellular carcinoma (HepG2) cells were obtained from the American Type Culture Collection (ATCC, Rockville, MD). The cells were grown on RPMI-1640 medium supplemented with $10 \%$ inactivated fetal calf serum and $50 \mu \mathrm{g} / \mathrm{ml}$ gentamycin. The cells were maintained at $37^{\circ} \mathrm{C}$ in a humidified atmosphere with $5 \% \mathrm{CO}_{2}$ and were subcultured two to three times a week.

\section{Evaluation of the antitumor activity using Viability assay:-}

The antitumor activity was evaluated on tumor cells. The cells were grown as monolayers in growth RPMI-1640 medium supplemented with $10 \%$ inactivated fetal calf serum and $50 \mathrm{ug} / \mathrm{ml}$ gentamycin. The monolayers of 10,000 cells adhered at the bottom of the wells in a 96-well microtiter plate incubated for $24 \mathrm{~h}$ at $37^{\circ} \mathrm{C}$ in a humidified 
incubator with $5 \% \mathrm{CO}_{2}$. The monolayers were then washed with sterile phosphate buffered saline (0.01 $\left.\mathrm{M} \mathrm{pH} 7.2\right)$ and simultaneously the cells were treated with $100 \mu \mathrm{l}$ from different dilutions of tested sample in fresh maintenance medium and incubated at $37^{\circ} \mathrm{C}$. A control of untreated cells was made in the absence of tested sample. A positive control containing Doxroubcin drug was also tested as reference drug for comparison. Six wells were used for each concentration of the test sample. Every $24 \mathrm{~h}$ the observation under the inverted microscope was made. The number of the surviving cells was determined by staining the cells with crystal violet (Mosmann, 1983; Gangadevi and Muthumary, 2007)) followed by cell lysing using 33\% glacial acetic acid and read the absorbance at 590nm using ELISA reader (SunRise, TECAN, Inc, USA) after well mixing. The absorbance values from untreated cells were considered as $100 \%$ proliferation.

The number of viable cells was determined using ELISA reader as previously mentioned before and the percentage of viability was calculated as [1-(ODt/ODc)]x100\% where ODt is the mean optical density of wells treated with the tested sample and ODc is the mean optical density of untreated cells. The 50\% inhibitory concentration $\left(\mathrm{IC}_{50}\right)$, the concentration required to cause toxic effects in $50 \%$ of intact cells, was estimated from graphic plots [22,23].

\section{Evaluation of cytotoxicity activity against the human liver cancer (HePG2) cell line:-}

The antitumor activities of compounds were assessed against HePG2 cancer cell line in comparison to the tradition anticancer drug (Doxorubicin) on the basis of monitoring the inhibition of the growth of human cancer cells, a series of synthesized compounds possessing a broader spectrum of antitumor activity. Eighty tested compounds $(2,3,4,5,6,7,8,9,10,11,12,13,14,15,16,17$ and 18) were subjected to a screening system for investigation of their antitumor potency against liver (HePG2) cell lines. The antitumor activity results indicated that most of the compounds showed inhibition activity against the tested cell line but varying intensity extents in comparison to the known anticancer drug (Doxorubicin) (See table 1).

5-(2-oxo-2H-chromen-3-yloxy) 4,7-dimethyl coumarin10 exhibited highly potent anticancer activity against HePG2 (figure10)cell line showing $\mathrm{IC}_{50}$ value $6.18(\mu \mathrm{g} / \mathrm{ml})$; respectively which represent comparable activity to the reference drug doxorubicin $\left(\mathrm{IC}_{50} 0.46(\mu \mathrm{g} / \mathrm{ml})\right.$. However, introduction of a chromen ring to the coumarin back bone through an oxo junction as in compound $\mathbf{1 0}$ afforded significant activity against HePG2 cell line..

Table 1:- Six dosage growth inhibition percent and $\mathrm{IC}_{50}$ values of the tested compounds against HePG2 cell line.

\begin{tabular}{|c|c|c|c|c|c|c|c|}
\hline \multirow[t]{3}{*}{ Comp. No } & \multicolumn{6}{|c|}{ Viability \% } & \multirow{3}{*}{$\begin{array}{c}\mathrm{IC}_{50}(\mu \mathrm{g} / \mathrm{ml})^{\mathrm{a}} \\
\text { HePG2 }^{\mathrm{b}}\end{array}$} \\
\hline & \multicolumn{6}{|c|}{ Sample concentration $(\mu \mathrm{g} / \mathrm{ml})$} & \\
\hline & $\mathbf{5 0}$ & 25 & 12.5 & 6.25 & 2.12 & 1.56 & \\
\hline 2 & 20.43 & 38.62 & 57.56 & 71.43 & 84.96 & 90.31 & 17.50 \\
\hline 3 & 46.47 & 79.89 & 87.62 & 91.14 & 96.35 & 98.47 & 47.40 \\
\hline 4 & 30.54 & 49.67 & 73.81 & 81.42 & 93.07 & 98.82 & 24.80 \\
\hline 5 & 10.79 & 26.04 & 42.97 & 75.61 & 89.84 & 93.23 & 11.20 \\
\hline 6 & 13.94 & 26.75 & 50.87 & 74.18 & 87.02 & 92.85 & 13.00 \\
\hline 7 & 27.89 & 65.92 & 74.05 & 81.72 & 90.63 & 94.82 & 35.50 \\
\hline 8 & 44.85 & 75.16 & 89.65 & 94.28 & 99.17 & 100.00 & 45.80 \\
\hline 9 & 31.59 & 63.16 & 76.58 & 82.91 & 90.67 & 96.24 & 35.40 \\
\hline 10 & 8.74 & 12.31 & 31.65 & 49.54 & 71.63 & 82.92 & 6.18 \\
\hline 11 & 68.42 & 89.03 & 96.14 & 99.71 & 100.00 & 100.00 & $>50$ \\
\hline 12 & 24.86 & 48.71 & 75.82 & 90.66 & 97.21 & 99.74 & 24.40 \\
\hline 13 & 29.74 & 57.86 & 68.14 & 81.23 & 90.69 & 96.12 & 32.00 \\
\hline 14 & 38.69 & 81.53 & 89.72 & 96.13 & 99.74 & 100.00 & 43.40 \\
\hline 15 & 12.93 & 29.28 & 71.89 & 82.74 & 91.43 & 97.24 & 18.90 \\
\hline 16 & 22.94 & 64.83 & 79.61 & 88.78 & 93.64 & 97.22 & 33.90 \\
\hline 17 & 28.75 & 54.69 & 73.12 & 89.41 & 93.86 & 96.72 & 29.50 \\
\hline 18 & 29.56 & 70.25 & 86.13 & 93.72 & 96.89 & 99.74 & 37.40 \\
\hline Doxorubicin $^{c}$ & 4.91 & 8.87 & 14.83 & 16.16 & 25.28 & 34.64 & 0.46 \\
\hline
\end{tabular}

${ }^{\mathrm{a}} \mathrm{IC}_{50}$,compound concentration required to inhibit tumor cell proliferation by $50 \%$.

${ }^{\mathrm{b}}$ Human liver cell line (HePG2)

${ }^{\mathrm{c}}$ positive control 


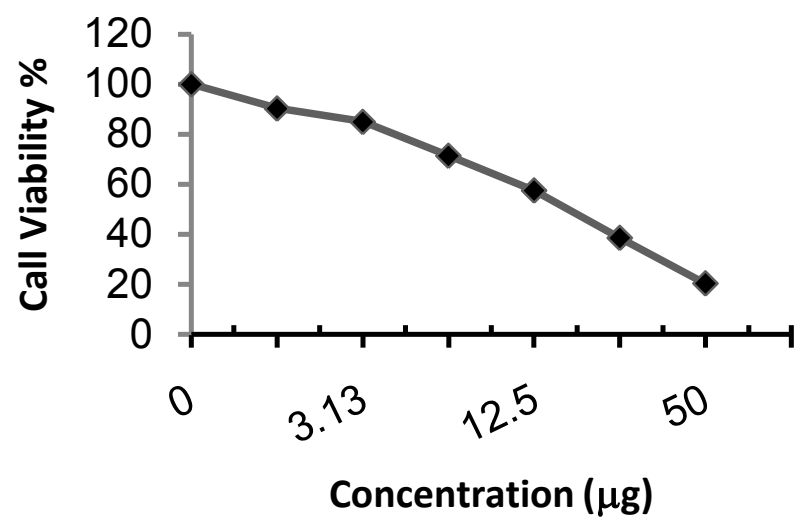

Figure 1:- The inhibitory effect of compound 2 concentration on HePG-2 cell activity.

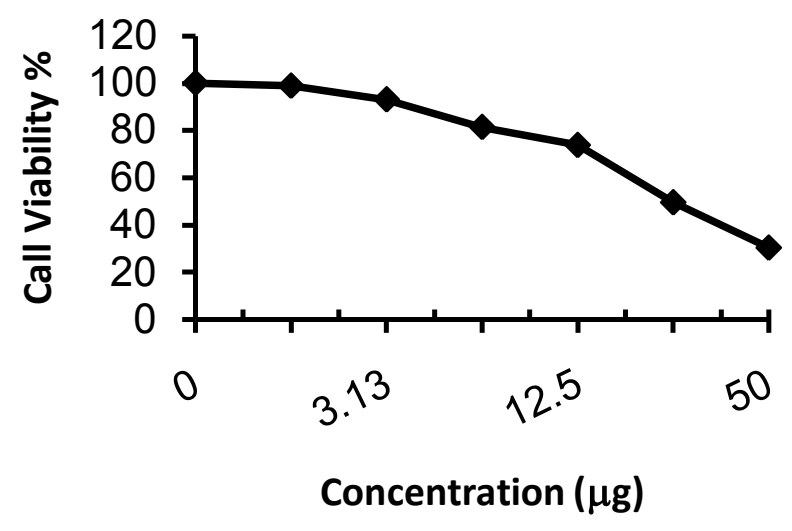

Figure 3:- The inhibitory effect of compound 4 concentration on HePG-2 cell activity.

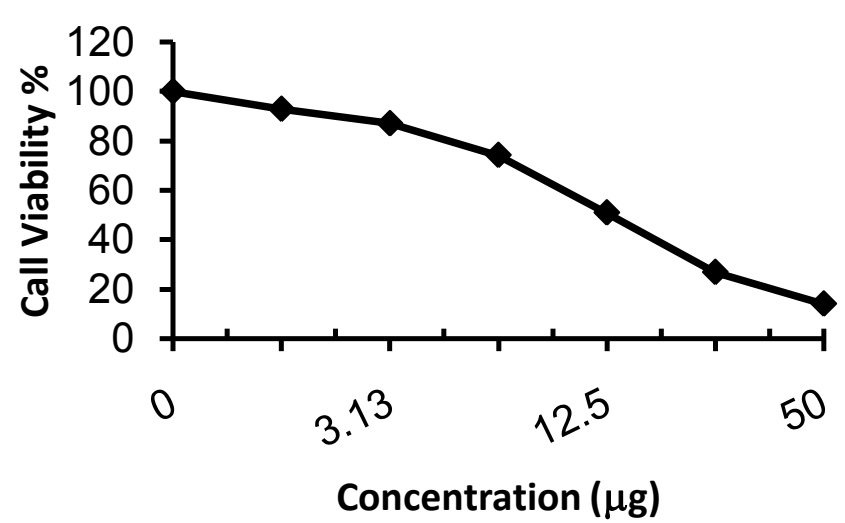

Figure 5:- The inhibitory effect of compound 6 concentration on HePG-2 cell activity.

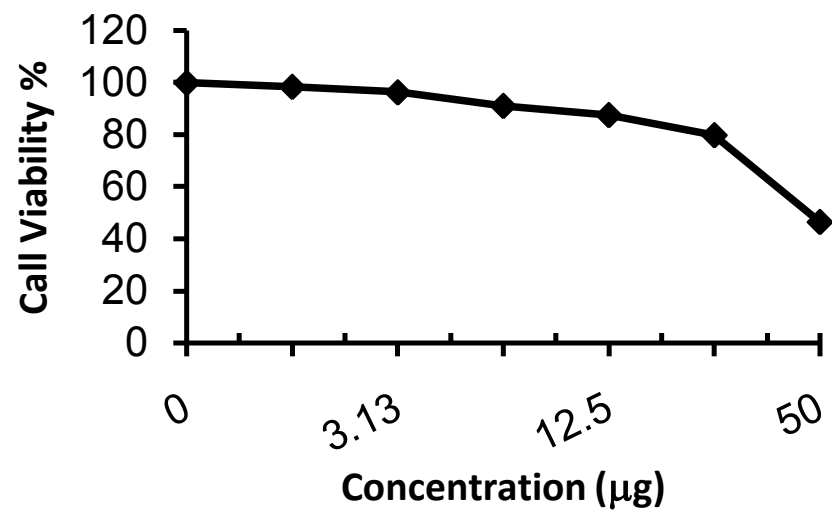

Figure 2:- The inhibitory effect of compound 3 concentration on HePG-2 cell activity.

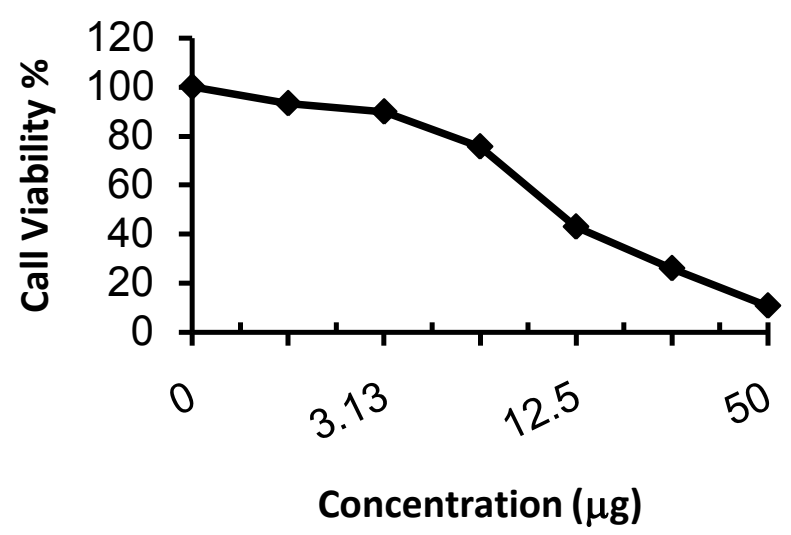

Figure 4:- The inhibitory effect of compound 5 concentration on HePG-2 cell activity.

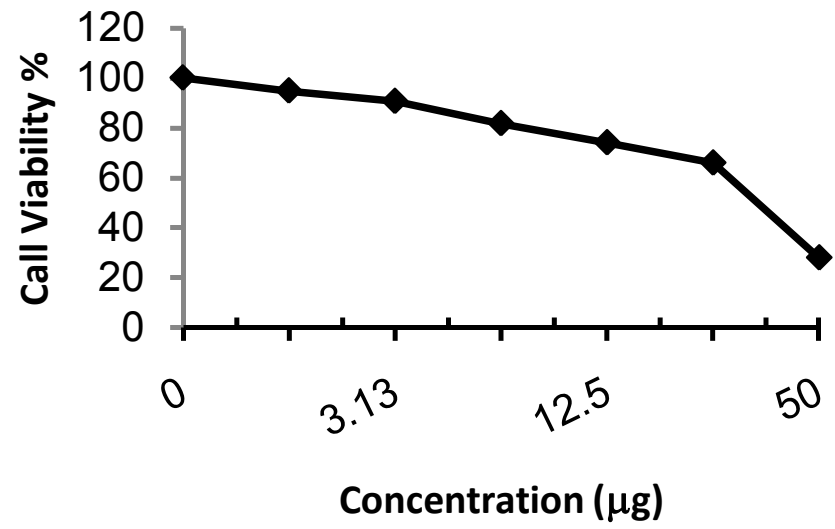

Figure 6:- The inhibitory effect of compound 7 concentration on HePG- 2 cell activity. 

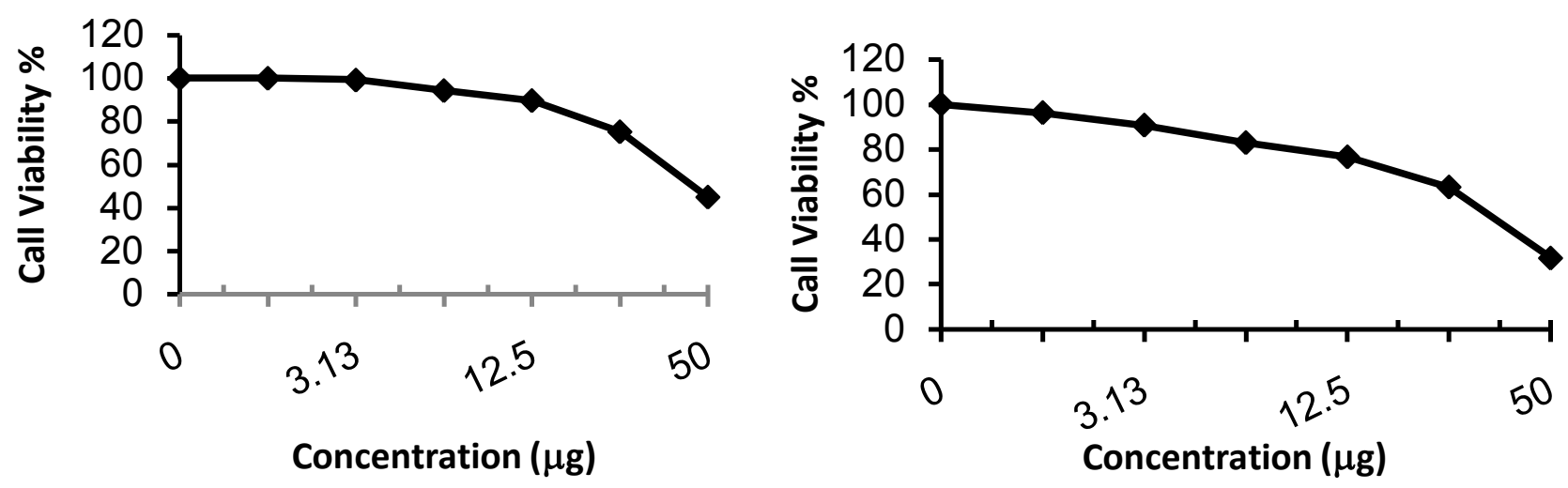

Figure 7:- The inhibitory effect of compound 8 concentration on HePG-2 cell activity.

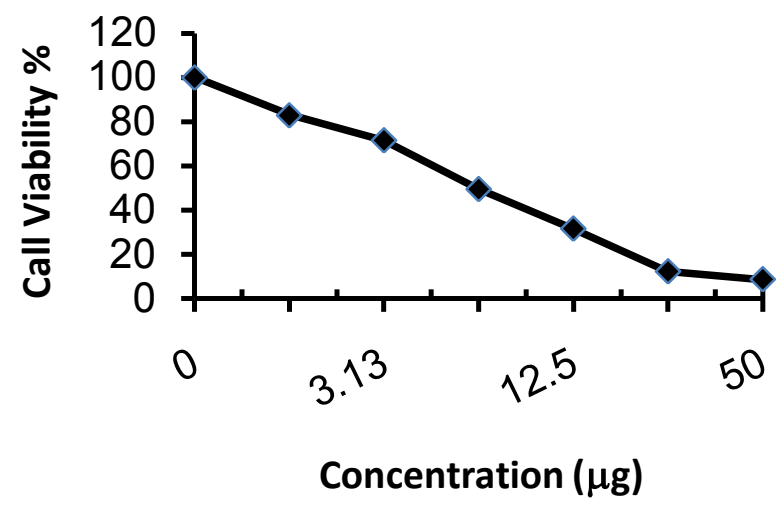

Figure 9:- The inhibitory effect of compound $\mathbf{1 0}$ concentration on HePG-2 cell activity

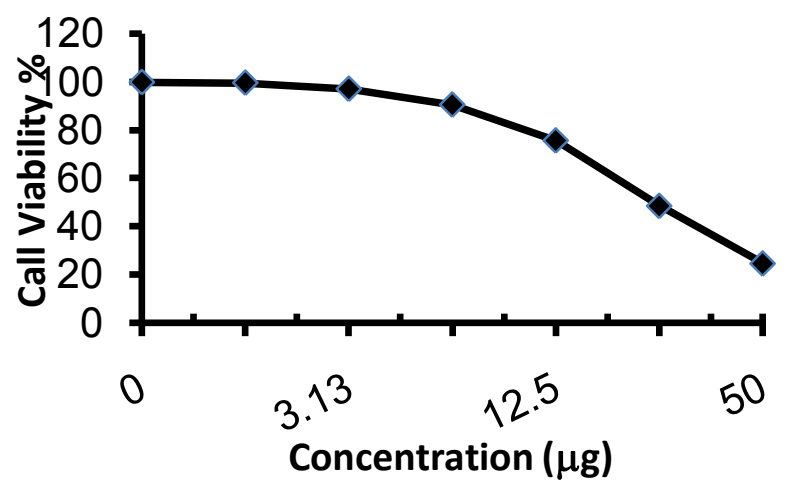

Figure 11:- The inhibitory effect of compound 12 concentration on HePG-2 cell activity.

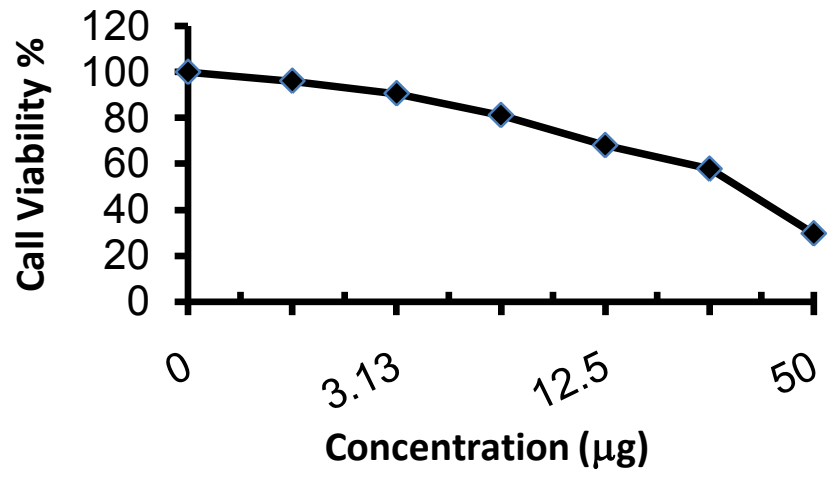

Figure 12:- The inhibitory effect of compound 13 concentration on HePG-2 cell activity. 


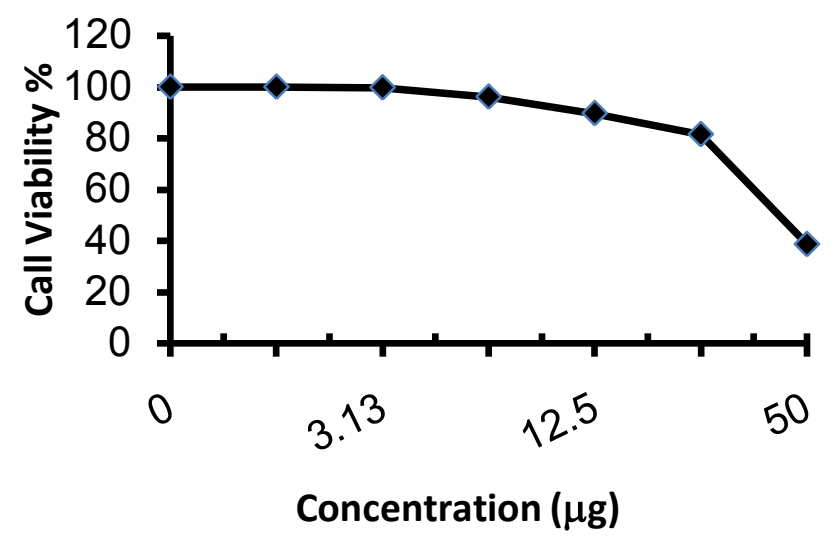

Figure 13:- The inhibitory effect of compound 14 concentration on HePG-2 cell activity.

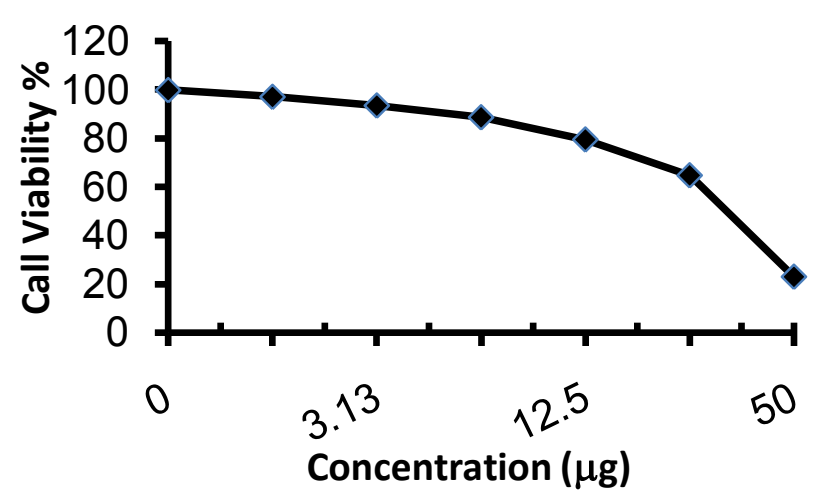

Figure 15:- The inhibitory effect of compound 16 concentration on HePG-2 cell activity.

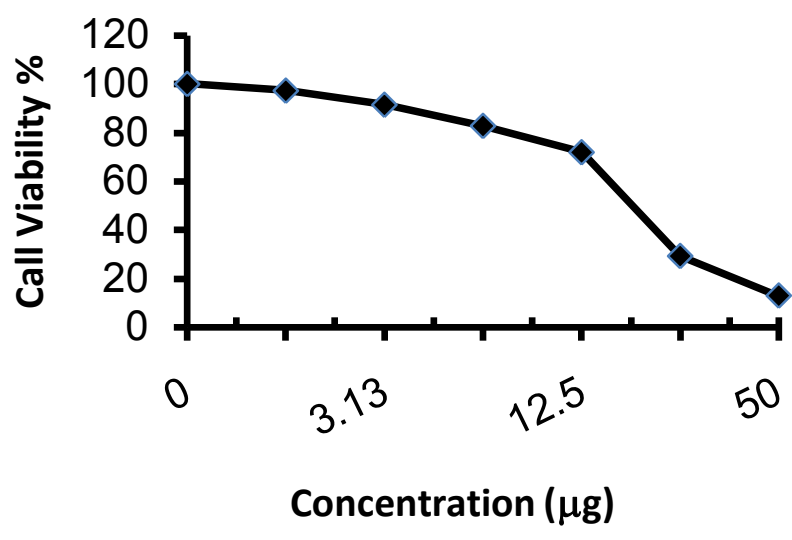

Figure 14:- The inhibitory effect of compound 15 concentration on HePG-2 cell activity

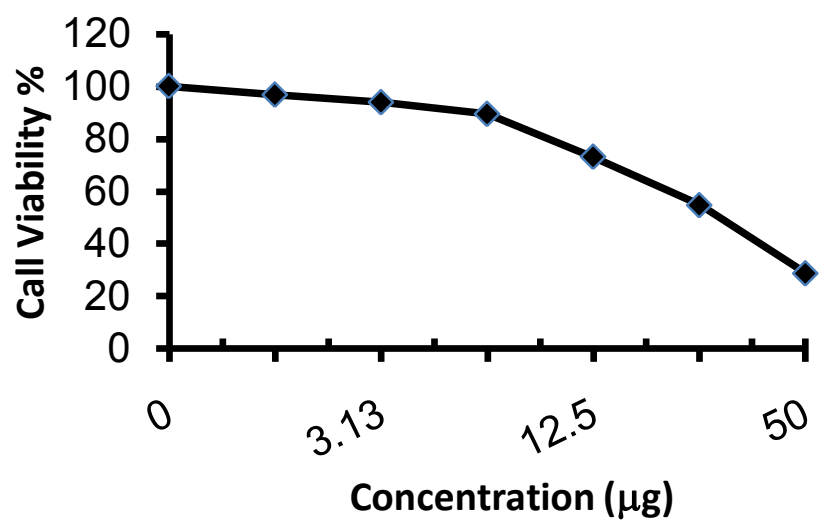

Figure 16:- The inhibitory effect of compound 17 concentration on HePG-2 cell activity.

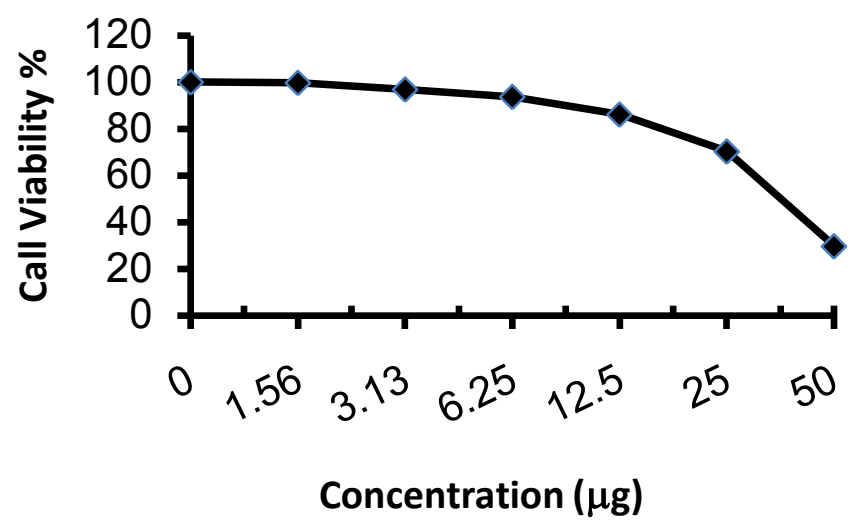

Figure 17:- The inhibitory effect of compound 18 concentration on HePG-2 cell activity.

\section{Conclusion:-}

Most of the compounds showed better activity against liver cancer HePG2 cell line. However compounds 2,5,6 and 15 showed moderate to strong activity against $\mathrm{HePG} 2$ with $\mathrm{IC}_{50}$ values ranging from 11.2-18.9 $(\mu \mathrm{g} / \mathrm{ml})$. compound 10 was the most active compound exerting anticancer activity comparable to the references drug doxorubicin against HePG2 cell line showing $\mathrm{IC}_{50}$ value $6.18(\mu \mathrm{g} / \mathrm{ml})$, while doxorubin exerted its $\mathrm{IC}_{50}$ value at $0.46(\mu \mathrm{g} / \mathrm{ml})$. 


\section{References:-}

1. Farshori, N.N.;Banday, M.R.; Ahmed, A.; Khan, A. U.;Rauf, A. 7-Hydroxy-coumarin derivatives : synthesis, Characterization and Preliminary antimicrobial activities. Medicinal Chemistry Research,2011, 20, 535-541.

2. $\quad$ Dekic B. R.;Radulovic N.S.;Dekic V.S.;Vukicevic, R.D.;Palic, R.M. Synthesis and Antimicrobial Activity of New 4Heteroarylamino coumarin derivatives containing Nitrogen and Sulfur as Heteroatoms, Molecules,2011,15(4), 22462256.

3. Sinhamahapatra, A.;Sutradhar, N.;Paharis Bajaj, H.C.; Panda, A.B. Mesoporous zirconium phosphate: An efficient catalyst for the synthesis of coumarin derivatives through Pechmann condensation reaction . Appl. Catal. A. Gen. ,2011, 394, 93-100.

4. Pankaj, A.;Sanjib, D.;Namita, A.; shish, G.; Baghel, U.S. Synthesis and Screening of some novel 7-hydroxy-4methyl coumarin derivatives for antipsychotic activity, International Journal of Pharmacy, Life Sciences,2010, 1,113118.

5. Upadhyay,K.K.;Mishra,R.K.; Kumar, A. A. convenient synthesis of some comarin derivatives using $\mathrm{SnCl}_{2} .2 \mathrm{H}_{2} \mathrm{O}$ as catalyst .Catal.Lett. 2008, 121, 118-120.

6. Kostova, L.; Synthetic and Natural coumarins as cytotoxic agents. Current medicinal chemistry Anti- cancer agents, 2009, 5, 29-46.

7. Lin, C.M.; Huang, S.T.; Lee, F. W.; Kuo, H. S. ; Lin, M. H . 6-Acyl-4- aryl/alkyl- 5, 7 -dihydroxycoumarins as antiinflammatory agents.Bio.Med. Chem. ,2006,14,4402-4409.

8. Manolov, I.; Moessmer, C. M.; Danchev, N. Synthesis, structure, toxicological and pharmacological investigations of 4-hydroxycoumarin derivatives , Eur. J. Med. Chem., 2006,41,882-890.

9. Curini, M.; Epifano, F.; Maltese,F.;Tubaro,M.A.; Altinier,G.; Gonzales,S. P. ; Rodriguez, J.C. Synthesis and antiinflammatory activity of natural and semisynthetic geranyloxycoumarins, Bio. Med. Chem. Lett. ,2004,14,22412243.

10. Sashidhara, K. V.; Kumar,A.; Kumar,M.; Sonkar,R.; Bhatia, G.; Khanna,A.k. Novel coumarin derivatives as potential antidyslipidemic agents, Bio. Med. Chem. Lett. 2010,20,4248-4251.

11. Kontogiorgis, C. A. ;Hadjipavlon- Litina, D.J. Synthesis and biological evaluation of novel coumarin derivatives with a 7-azomethine linkage . Bio. Med. Chem. Lett. 2013,24,227-229.

12. Lad, H. B.; Giri, R. R.; Brahmbhatt,D. I. An efficient synthesis of some new -3-bipyridinyl substitutedcomarins as potent antimicrobial agents. Chinese chemical letters, 2013,24,227-229.

13. Hwu,J. R.; Singha,R.; Hong,S. C.;Chang,Y. H.; Das, A.R. ; Vliegen,I.; Clercq,E. D. Synthesis of new benzimidazolecoumarin conjugates as anti-hepatitis C virus agents. Neyts, J. Antiviral Research,2008,77,157-162.

14. Devji, T.; Reddy,C.; Woo,C.;Awale, S.; Kadota,S.; Carrico- Moniz,D.; Pancreatic anticancer activity of a novel geranylgeranylatedcoumarin derivative. Bio. Med. Chem. Lett. 2011,21,5770-5773.

15. Belluti,F.; Fontana,G.; Dalbo, L. ; Carenini, G. ; Zunion, F. ; Design,Synthesis and anti- cancer activities of stilbenecoumarin hybrid compounds: Identification of novel proapoptotic agents. Bio.Med. Chem. 2010, 18, 3543-3550.

16. Refouvelet, B.; Guyon, C.; Jacquot, Y.; Girarol, C.; Fein, H.; Bevalot, F.; Robert, J-F.; Heyol, B.; Mantions, G. Richert, L.; Xicluna, A.Synthesis of 4- hydroxycoumarin and 2,4-quinolinediol derivatives and evaluation of their effects on the viability of HePG2 cells and human hepatocytes culture.Eur. J. Med. Chem. ,2004, 39, 931-937.

17. Jacquot, Y.; Bermont, L.; Giorgi, H. ; Refouvelet, B.; Adessi, G.L.; Daubrosse, E.; Xicluna,A.3-Substituted benzopyrano- benzothiazinones: Synthesis and estrogenic activity on MCF-7 breast carcinoma cell. Eur. J. Med. Chem. ,2001, 36, 127-136.

18. Albodi, J.; Shirini, F.; Abasi, J.; Armand, N.; Motaharizadeh, T.; A green, efficient and recyclable poly (4vinylpyridine)- supported copper iodide catalyst for the synthesis of coumarin derivatives udner free conditions. J. C.R. Chimie,2013, 16, 407-411.

19. Bhimashankar, R.P.;Hanumant, G.; Vijay, V.B.; Ethyl acetate synthesis by esterification of acetic acid with ethanol over a heteropoly acid on montamrilloniteK $\mathbf{1 0}_{\mathbf{1 0}}$. Indian J. Streams Res. ,2011, 1, 227-231.

20. Jayashree, A.; Rao, V.S.; Darbarwar, M.;Synthesis of 5H-quinolin[3,4-b][1,4]benzothiazin-6(12H)-ones. Synth. Commun. ,1990, 20(7), 919-924.

21. Abass, M.; Othman, E.S.; Chemistry of substituted quinolines: Synthesis and reactions of some novel 3-pyrazolyl-2quinolinones. Synth. Commun. ,2001,21, 3361-3376.

22. Mosmann, T.; Rapid colorimetric assay for cellular growth and survival: proliferation and cytotoxicity assays. J. Immunol. Methods, 1983, 65, 55-63.

23. Gangadevi, V. and Muthumary, J. Prelimianry studies on cytotoxic effect of fungal taxol on cancer cell lines. African Joruanl of Biotechnolgy,2002, 6, 1382-1386. 